\title{
Highlights of the XIV Congress of the Polish Society of Nuclear Medicine, Lublin, 28-30"h May, 2014
}

Rafał Czepczyński

A highlights lecture is never an easy task. First of all, it is difficult to summarize such enormous amount of scientific data presented during the congress. Secondly, it carries a risk that some omitted authors will be disappointed by avoiding their contribution. Finally, as stated by Cugowski et al. in his first presentation, „I know well that it's too late to start all over again" [1]. Nevertheless, I must start and I am starting with an interesting presentation by our hosts here, in Lublin. They tested a new image acquisition regimen of parathyroid scans. Several protocols are used nowadays to visualize parathyroid adenomas using ${ }^{99 \mathrm{~m} T c-M I B I}$ : planar subtraction scans, SPECT and SPECT/CT. Pachowicz et al. proposed a protocol in which at first ${ }^{99 m} \mathrm{~m}$ C-pertechnetate SPECT of the neck and chest is registered followed by ${ }^{99 m} \mathrm{TC}-\mathrm{MIBI}$ injection and another SPECT acquisition 15 min later. The acquisition is completed by CT scan without moving the patient off the gamma camera's bed. The CT data of this acquisition are used for attenuation correction and anatomical correlation of both SPECT images. A presented selection of cases showed impressive results. Necessity of prolonged immobilization of the patient during the entire procedure seems to be the only disadvantage [2].

There were three independent studies dealing with the problem of thyroid incidentaloma in different imaging procedures. Giejda et al. reviewed myocardial perfusion images using ${ }^{99 m} \mathrm{Tc}-\mathrm{MIBI}$ in 354 patients and found as many as 41 cases (11.6\%) of tracer accumulation in the thyroid gland. Thorough evaluation of all these cases led to detection of just one case of previously unknown differentiated thyroid carcinoma. The remaining cases represented different forms of benign thyroid disease [3]. In 1150 PET/CT scans with ${ }^{68} \mathrm{Ga}-\mathrm{DOTA}$-TATE focal thyroid activity was found by Kunikowska et al. in 12 cases (1.0\%). Similarly, just one of them was caused by differentiated thyroid cancer [4]. Finally, among 6614 patients who had had PET/CT scans using ${ }^{18} \mathrm{~F}-\mathrm{FDG}, 122$ (2.3\%) had focal tracer accumulation in the thyroid gland. $29.2 \%$ of evaluable cases were finally diagnosed with thyroid malignancies [5]. So, what we learned from these three retrospective analyses is that, surprisingly, thyroid accumulation is seen most frequently at ${ }^{99 m} \mathrm{Tc}-\mathrm{MIBI}$ scans (perhaps due to the presence of free technetium), but it is almost always caused by benign disease. Thyroid incidentalomas are rare in PET/CT scans (both ${ }^{68} \mathrm{Ga}$-DOTA-TATE and ${ }^{18} \mathrm{~F}$-FDG), but if they occur in ${ }^{18} \mathrm{~F}-\mathrm{FDG}$ scans, the risk of differentiated thyroid carcinoma is relatively high.

Three interesting contributions from Białystok about radioiodine treatment of benign thyroid disease were presented, both performed on large patient cohorts. One of them, performed in 700 patients with Graves' disease, analyzed retrospectively different factors influencing the efficacy of radioiodine therapy. After 1 year of follow-up, the highest success rate was observed in patients with goiters of less than $50 \mathrm{ml}$ who received the dose of 150 Gy. In patients with larger goiters (> $50 \mathrm{ml}$ ) required 200 Gy to treat hyperthyroidism [6]. In another presentation, the problem of radioiodine therapy in subclinical hyperthyroidism was evaluated. Abdelrazek et al. could present excellent results of the treatment with complete euthyroid status achieved in as many as $94 \%$ of patients with nodular goiter and in $99 \%$ of patients with toxic adenoma [7]. According to the authors, the success of therapy should be attributed to strict individualization of radioiodine dose estimation including calculation of effective half-life of radioiodine and proper preparation of patients. Finally, Mojsak et al. shared with us their experiences with rhTSH to improve efficacy of radioiodine therapy in patients with non-toxic nodular goiter who had presented with low iodine uptake. Injection of rhTSH was able to increase iodine uptake from $33 \%$ at baseline to $75 \%$. It resulted in better reduction of thyroid volume in comparison to the control group that was treated using radioiodine without rhTSH (48\% vs. $31 \%$ of volume reduction) [8].

As usually, there were several reports concerning neuroendocrine tumors (NETs). Regarding the classical imaging of NETs, a nice overview of ${ }^{99 m}$ Tc-HYNIC-TOC scintigraphy based on a huge number of 1200 scans was delivered by Ćwikła et al. [9]. In different clinical settings (staging, restaging, unknown primary etc.) sensitivity and specificity were as high as $90-100 \%$. Somatostatin receptor scintigraphy is not that effective in all NETs. In insulinoma, the expression of somatostatin receptors is relatively low. Therefore, we were glad to hear good news from Cracow about recent possibilities of tumor visualization using radiolabeled analogs of GLP-1 [10]. Hubalewska-Dydejczyk et al. presented very encouraging images obtained with ${ }^{99 m} \mathrm{Tc}-$-exendin-4 and ${ }^{111} \mathrm{In}$-exendin-4. These newly developed analogs were tested in 55 patients with insulinoma or some other NETs, showing high diagnostic accuracy.

"Do we need ${ }^{18} \mathrm{~F}$-FDG PET/CT to qualify a patient with NET to PRRT?" - this question was raised by Kunikowska et al. In order to provide the answer, she analyzed 30 patients who had PET/CT with both radionuclides: ${ }^{18} \mathrm{~F}-\mathrm{FDG}$ and ${ }^{67} \mathrm{Ga}$-DOTA-TATE. As we would expect the patients with positive ${ }^{18} \mathrm{~F}-\mathrm{FDG}$ examination had worse prognosis when it comes to the progression-free survival and overall survival [11]. So, the answer was: yes, ${ }^{18} \mathrm{~F}-\mathrm{FDG}$ is useful, especially for prognosis.

With regard to the treatment of NETs, an elegant, randomized study of long acting somatostatin analogs as consolidation therapy after peptide receptor radionuclide therapy (PRRT) in advanced NETs was presented by the group from Oncology Centre in Gliwice [12]. In as many as 79 patients subjected to PRRT followed by continuous "cold" analog treatment, the results of therapy in terms of time-to-progression were compared with 46 patients who did not 
receive the "cold" analog. Surprisingly, there was no statistical difference after mean follow-up of 34 months post PRRT. These results, as soon as they are published, should be seriously taken into account in the discussion on the treatment of disseminated NETs.

Thyroid cancer was discussed in several presentations. One of them, originating from Belarus, was dedicated to children with thyroid cancer after Chernobyle nuclear accident. The new epidemiologic data provided by Baranovsky and Demidchyk [13], showed that young patients with irradiation-related thyroid cancer had excellent survival (99\% in 10 years) despite regular occurrence of pulmonary metastases $(97.5 \%)$ and quite frequent non-complete remission after surgery and RIT.

${ }^{18} \mathrm{~F}-F D G$ PET/CT evaluation of adrenal lesions has always been an interesting issue. In another study by Kunikowska et al., different imaging parameters were analyzed in 102 non-functioning adrenal tumors that were subsequently surgically removed [14]. Among these parameters (e.g. Hounsfield units, tumor diameter), two were found to be of prognostic value. Maximal standardized uptake value (SUVmax) above 5.2 and adrenal-to-liver SUVmax ratio above 1.53 were indicating the malignant character of the lesion. Moreover, the latter parameter was found to be an independent prognostic factor.

False-positive and false-negative results of PET/CT using 18 F-FDG in patients suspected for recurrence of colorectal cancer were discussed by Fijotek-Warszewska et al. [15]. The authors found ca. $5 \%$ of false-positive findings caused by mediastinal lymph-nodes activity, FDG uptake in the vicinity of the colon anastomosis and by intestinal infestation. Another $5 \%$ of the scans were false-negative. The undetected lesions were located in the brain, around the bladder and in the liver (small metastases). Performing PET/CT shortly after chemotherapy did also cause false-negative scans.

One of a few presentations addressing the issue of treatment monitoring by PET/CT was presented by colleagues from the same center in Warsaw. Response to neoadjuvant chemotherapy in young patients with sarcomas originating in bones was evaluated with 18F-FDG PET/CT [16]. Decrease of SUVmax between initial and post-therapy scans images showed good correlation with the histopathological assessment of tumor necrosis.

Nobody knows how it happened that in two cities, Cracow and Poznan, the same problem was independently studied. In both contributions, ovarian cancer recurrence in correlation with CA-125 marker level was evaluated using ${ }^{18} \mathrm{~F}-\mathrm{FDG}$ PET/CT. Both groups have found that the grade of CA-125 elevation does not predict the localization of the recurrence or metastases [17, 18]. Additionally, Fularz et al. defined the cut-off value of CA-125 concentration of $17.6 \mathrm{U} / \mathrm{ml}$ to optimize the diagnostic accuracy of PET/CT [18]. Patients with marker levels above this value are likely to have a positive PET/CT scan, showing recurrence of ovarian cancer.

Other PET tracers are studied in the PET/CT center in Bydgoszcz. ${ }^{18} \mathrm{~F}-\mathrm{FLT}$ was used to evaluate neoadjuvant chemotherapy in 35 patients with breast cancer. SUVmax reduction did not correlate with the reduction of Ki-67 proliferation index [19]. In patients with prostate cancer, the same group lead by B. Małkowski reported that ${ }^{11} \mathrm{C}$-acetate PET/CT showed higher sensitivity in the detection of bone metastases in comparison to classical bone scintigraphy [20].

Several presentations during this congress were devoted to radionuclide therapy. Łuka et al. summarized their experience with radiosynovectomy in patients with psoriatic arthritis. According to them, the first course of radiosynovectomy of the knee is frequently ineffective [21]. Fortunately, the patients usually respond to the second course of radiosynovectomy performed 6 months later. Dosimetric measurement of radiosynovectomy performed with ${ }^{90} Y$ is difficult due to beta-emission of this radionuclide. However, two possibilities of dosimetric evaluation were proposed by two groups. Zorga et al. injected intraarticularly ${ }^{99 \mathrm{~m} T c-s u l f u r}$ colloid together with ${ }^{90}$ Y-colloid in patients with juvenile arthritis, and assessed distribution of the radionuclide using a gamma camera [22]. Chojnowski et al. proposed PET/CT registration of the treated knee joints $4-5$ days after injection of ${ }^{90} \mathrm{Y}$ [23].

A novel radioembolization regimen in patients with liver metastases was discussed in details by a Polish-Canadian group formed by J. Ćwikła (Olsztyn), M.L. Nowicki (Warsaw) and A. Celler (Vancouver). Their studies are concentrated on 188-rhenium microspheres instead of commonly used ${ }^{90} Y$ spheres. ${ }^{188}$ Re has many advantages over ${ }^{90} Y$; one of them is gamma-emission. Dosimetry using SPECT technique showed correlation between mean tumor dose and overall survival. The treatment was well-tolerated and further clinical experience is required to optimize the treatment [24, 25].

Bączyk et al. presented new data collected on a group of 187 patients with bone metastases of prostate cancer treated with ${ }^{153} \mathrm{Sm}$-EDTMP. The group found that adjuvant treatment with intravenous bisphosphonates did improve analgesic effect of ${ }^{153} \mathrm{Sm}$-EDTMP in mixed, but not in osteoblastic metastases that are present actually in majority of the patients [26]. The same authors also addressed the rather rarely studied issue of psychological impact of radionuclide therapy in the palliative setting. Based on a well-designed study protocol, the group was able to provide evidence that ${ }^{153} \mathrm{Sm}$-EDTMP therapy, by its significant analgesic effect, markedly reduces depression, anxiety and aggressive behavior [27].

Several interesting studies were presented in cardiological sessions of the congress. Kobylecka et al. studied the impact of glucose concentration on the quality of myocardial ${ }^{18} \mathrm{~F}-\mathrm{FDG}$ PET/CT surprisingly finding no correlation at all [28]. In a study by Siennicki et al. clear evidence of the positive impact of attenuation correction on the sensitivity and specificity of myocardial perfusion imaging

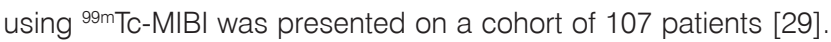
This message will be welcome by the manufacturers of SPECT/CT scanners: the attenuation correction does really work in the heart studies..

Another study from Łódź considered the shortening of SPECT/CT acquisition time by half in order to enhance scanner's capacity [30]. The authors found that although the image quality was satisfactory and the results of global myocardial contractility were comparable in "short" and "normal" acquisitions, the evaluation of perfusion was slightly different in both regimens leading to some false clinical conclusions. Thus, shorter acquisition is not recommended. I would add that it is completely unnecessary as the authorities extend the working time in nuclear medicine and radiology department in Poland this year...

Our community is gathering experience with gamma cameras equipped with cadmium-zirconium detectors (CZD). Piszczek et al. found that prone position of the patient during myocardial perfusion data acquisition eliminates perfusion artifacts, especially in the inferior wall of the left ventricle. Prone position modified diagnosis in as many as $50 \%$ of the patients [31]. Myocardial adrenergic activity was examined by the congress organizer, B. Chrapko, in patients with chronic renal failure and with atrial fibrillation using ${ }^{123}$ |-MIBG scintigraphy. She found that both patient groups had 
increased myocardial tracer accumulation with higher activity in the group with atrial fibrillation [32].

Radionuclide diagnosis of pulmonary embolism (PE) remains a hot issue with the introduction of novel imaging techniques. Mazurek et al. presented convincing data on the use of SPECT/CT to evaluate pulmonary perfusion in a group of 84 patients suspected of PE [33]. They reported that SPECT/CT acquisition of perfusion images showed better diagnostic performance in comparison to planar images and SPECT images alone. Moreover, ventilation scans did not provide any additional value to the diagnosis obtained with SPECT/CT, so they concluded that ventilation scans could be avoided. On the contrary, in a study by Kovacević-Kuśmierek et al., lung perfusion acquired with SPECT/CT was not advantageous over planar images in the prognosis of respiratory function in patients planned for lobectomy or pulmonectomy due to lung cancer [34].

Another group from Łódź defined pharmacokinetic parameters of ${ }^{99 m} \mathrm{Tc}$-ethylenecystein (EC) used for the dynamic renal scans as an alternative to ${ }^{99 m}$ Tc-MAG3. They found that both, mean renal transit time and parenchymal transit time are shorter in case of EC than for MAG3 and DTPA [35].

There were only few abstracts dealing with neuroimaging. One of them, by Nocuń et al., reported that one of the automatic software designed for the evaluation of cerebral perfusion SPECT was sufficiently reliable when larger perfusion lesions were present. Visual inspection of the images, however, seemed more accurate in case of smaller defects [36].

As usually, the congress gathered many highly professional presentations in the field of radiopharmacy, mostly contributed by the National Institute of Nuclear Research. It is difficult to summarize them here, due to highly specialistic character of the presented data. One of the studies concentrated on the development of gastrin analogs labeled with radiometals $\left({ }^{90} \mathrm{Y},{ }^{177} \mathrm{Lu}\right.$ and $\left.{ }^{68} \mathrm{Ga}\right)$ [37]. The molecular structure of the complexes is dependent on the metal used. Another important issue is the development of alternative methods of production of technetium. The project under the auspices of International Atomic Energy Agency deals with obtaining ${ }^{99 m} \mathrm{Tc}$ by bombarding enriched ${ }^{100} \mathrm{Mo}$ with protons. As reported by Cieszykowska et al., the scientists work on the method of preparation of molybdenum target and recycling of ${ }^{100} \mathrm{Mo}$ after obtaining ${ }^{99 m}$ Tc from the target [38].

Physicists provided also interesting contribution to the congress. Tomaszuk et al. worked on the optimization of PET/CT protocol aimed at the reduction of dose equivalent using phantom studies. They found that modification of CT current and voltage did not influence PET reconstruction and SUV values of large lesions. In case of smaller lesions, automatic current modulation was of special value [39]. Different methods of image reconstruction were studied on phantoms and on patients by Wyszomirska et al. They found that the method of reconstruction had little impact on the evaluation of the images. Differences of SUV measurements using various reconstruction protocols were significant only in case of higher SUV values [40].

Budzyńska et al. measured the efficacy of lead shielding coats worn by the staff. The results showed that $0.5 \mathrm{~mm}$ layer of lead in the protecting coats is quite efficient in case of low energy gamma radiation. The efficacy is even better if the radiation source is located in patient's body [41]. It was explained that radiation scattering decreases the photons' energy, leading to a higher reduction of radiation dose on the other side of the tested shielding.
Interesting findings were published by Dziel et al. They compared measurements of activity of ${ }^{89} \mathrm{Sr}$ and ${ }^{90} \mathrm{Y}$ in different counters disseminated across the country. The differences between the measured values and the actual calibrated activity were up to 20-31\% [42].

So we could conclude that not all is true what we are measuring. Moreover, Izabela Trojanowska disclosed at the opening of the congress, "truth and lies equally rule my entire life" [43]. Should this hold true for the whole content of our congress, only half of the information summarized by me is correct. Which half is it? I do not know. I am leaving that to you to decide... Thank you for your attention.

\section{References}

1. Cugowski K. Budka Suflera, Sen o dolinie. Underground, 1993.

2. Pachowicz M, Chrapko B. SPECT + SPECT + CT protocol in hyperparathyroidism. Nucl Med Rev 2014; 17 (Suppl A): A34-35.

3. Giejda A, Kamiński G. Ocena charakteru przypadkowo rozpoznanych ogniskowych zaburzeń wychwytu ${ }^{99 m} T c-M I B I$ w tarczycy w trakcie scyntygrafii perfuzyjnej mięśnia sercowego. Nucl Med Rev 2014; 17 (Suppl A): A40.

4. Kunikowska J, Matyskiel R, Zemczak A et al. Przypadkowo wykryte zmiany w tarczycy w badaniu PET/CT z ${ }^{68}$ Ga-DOTATATE u pacjentów diagnozowanych z powodu nowotworu neuroendokrynnego. Nucl Med Rev 2014; 17 (Suppl A): A30.

5. Stangierski A, Woliński K, Czepczyński R, Ruchała M. Occurance of increased metabolism in thyroid gland in routine PET/CT studies. Nucl Med Rev 2014; 17 (Suppl A): A38-39.

6. Szumowski P, Kociura Sawicka A, Abdelrazek S, Mojsak M, Kostecki J, Myśliwiec J Radiojodoterapia w chorobie Gravesa: czynniki wpływające na skuteczność leczenia. Nucl Med Rev 2014; 17 (Suppl A): A33.

7. Abdelrazek S, Szumowski P, Mojsak M, Myśliwiec J. Wpływ radiojodoterapii na skuteczność leczenia pacjentów z subkliniczną nadczynnością tarczycy w oparciu o analizę retrospektywną. Nucl Med Rev 2014; 17 (Suppl A): A33.

8. Mojsak M, Abdelrazek S, Rogowski F et al. Wpływ rhTSH na efektywność radiojodoterapii w wolu guzkowym nietoksycznym. Nucl Med Rev 2014; 17 (Suppl A): A42-43.

9. Ćwikła JB, Lewczuk A, Wachuła E, Pawlak D, Janota B, Mikołajczak R. Clinical value of WB SPECT somatostatin receptor scintigraphy using ${ }^{99 m}$ TC-HYNIC-TOC, to evaluate patients with well-differentiated gastroenteropancreatic neuroendocrine neoplasm/tumors. Nucl Med Rev 2014; 17 (Suppl A): A30-31.

10. Hubalewska-Dydejczyk A, Sowa-Staszczak A, Pach D et al. Scyntygrafia analogiem GLP-1 znakowanym ${ }^{99 m}$ Tc oraz ${ }^{111}$ In -3 lata doświadczeń. Nucl Med Rev 2014; 17 (Suppl A): A29-30.

11. Kunikowska J, Pawlak D, Kos-Kudła B, Bednarczuk T, MikołajczakR, Królicki L. Czy potrzebujemy badania PET/CT z ${ }^{18}$ F-FDG do kwalifikacji pacjentów do terapii znakowanymi analogami somatostatyny (PRRT)? Nucl Med Rev 2014; 17 (Suppl A): A1.

12. Syguła A, Handkiewicz-Junak D, Hasse-Lazar K et al. Leczenie konsolidacyjne długodziałającymi analogami somatostatyny po leczeniu izotopowym nowotworów neuroendokrynnych. Nucl Med Rev 2014; 17 (Suppl A): A2.

13. Baranovski A, Demidchik Y. Common differentiated thyroid carcinoma in childhood and adolescence and the role of radioiodine in its treatment results of a retrospective analysis. Nucl Med Rev 2014; 17 (Suppl A): A41.

14. Kunikowska J, Matyskiel R, Totounchi S et al. Przydatność badania PET/CT $\mathrm{Z}^{18} \mathrm{~F}-\mathrm{FDG}$ do różnicowania zmian w nadnerczach. Nucl Med Rev 2014; 17 (Suppl A): A13.

15. Fijołek-Warszewska A, Łapińska G, Bryszewska M, Dedecjus M. Analiza fałszywych wyników badania F ${ }^{18}$-FDG PET/CT u pacjentów z podejrzeniem wznowy raka jelita grubego. Nucl Med Rev 2014; 17 (Suppl A): A15.

16. Bryszewska M, Łapińska G, Fijołek-Warszewska A et al. Wartość badania PET-CT w ocenie odpowiedzi na chemioterapię drobnokomórkowych mię- 
saków kości (mięsaków z rodziny Ewinga i mięsaków kościopochodnych) w korelacji z oceną histopatologiczną. Nucl Med Rev 2014; 17 (Suppl A): A14-15.

17. Sowa-StaszczakA, Buziak-Bereza M, Kołodziej M et al. Diagnostyka chorych z rozsiewem raka jajnika przy wykorzystaniu ${ }^{18}$ F-FDG. Nucl Med Rev 2014; 17 (Suppl A): A37.

18. Fularz M, Adamiak P, Czepczyński R et al. Diagnostyka wznowy raka jajnika przy pomocy PET/CT z użyciem ${ }^{18} \mathrm{~F}-\mathrm{FDG}$ w zależności od stężenia markera CA-125. Nucl Med Rev 2014; 17 (Suppl A): A15-16.

19. Małkowski B, Chmielowska E, Studziński M et al. Wczesna ocena skuteczności terapii neoadiuvantowej za pomocą FLT PET/CT w raku piersi — wyniki wstępne. Nucl Med Rev 2014; 17 (Suppl A): A10-11.

20. Małkowski B, Wróbel M, Małkowski B et al. Porównanie wartości badania scyntygraficznego układu kostnego z oceną układu kostnego w badaniach PET/CT wykonanych za pomocą ${ }^{11} \mathrm{C}$ Octanu w grupie pacjentów z rakiem prostaty. Nucl Med Rev 2014; 17 (Suppl A): A11.

21. Łuka K, Sulima-Gillow M. Radiosynowektomia izotopowa w leczeniu łuszczycowego wysiękowego zapalenia stawów kolanowych. Nucl Med Rev 2014; 17 (Suppl A): A5-6.

22. ZorgaP,Bobrowska-SnarskaD, Piwowarska-BilskaH, ListewnikMH, BirkenfeldB, Szałkowska M. Zagrożenie radiacyjne związane z radiosynowiortezą kolan u dzieci — doniesienie wstępne. Nucl Med Rev 2014; 17 (Suppl A): A18.

23. Chojnowski MM, Kobylecka M, Płazińska M, Fronczewska-Wieniawska K, Królicki L. PET/CT after yttrium-90 radiosynovectomy — detection of extra-articular activity. Preliminary study. Nucl Med Rev 2014; 17 (Suppl A): A43.

24. Nowicki ML, Sankowski A, Pawlak D et al. Wstępne badanie klinicznego użycia radioembolizacji za pomocą ${ }^{188}$ Re-Human Serum Albumin (HSA) mikrosfer u chorych na progresywną, nieresekcyjną postać pierwotnych lub wtórnych nowotworów złośliwych wątroby. Nucl Med Rev 2014; 17 (Suppl A): A3.

25. Shcherbinin S, Bator A, Grimes J et al. 3D spersonalizowana dozymetria po zabiegach radioembolizacji z użyciem ${ }^{188}$ Re Human Serum Albumin mikrosfer (HSA) w leczeniu chorych na zaawansowane nowotwory pierwotne i przerzutowe wątroby, oparte na ilościowych badaniach poterapeutycznych SPECT. Nucl Med Rev 2014; 17 (Suppl A): A6.

26. Bączyk M, Milecki P, Czepczyński R, Oleksa R, Czarnywojtek A, Ruchała M. Bisfosfoniany zwiększają efekt przeciwbólowy izotopu samaru 153 w terapii osteolityczno-osteoblastycznych przerzutów nowotworowych raka prostaty do kości Nucl Med Rev 2014; 17 (Suppl A): A4-5.

27. Bączyk M, Milecki P, Gut P, Wyszomirska A, Ruchała M. Ocena stanu emocjonalnego pacjentów z bolesnymi przerzutami nowotworowymi do kości w trakcie terapii radioizotopem samaru 153. Nucl Med Rev 2014; 17 (Suppl A): A5.

28. Kobylecka M, Bąk M, Chojnowski MM et al. Ocena żywotności mięśnia sercowego w badaniu FDG-PET/CT: czy jakość obrazu jest związana z poziomem glukozy we krwi? Analiza zmian poziomu glukozy w u chorych normoglikemicznych w protokole dożylnego obciążenia glukozą. Nucl Med Rev 2014; 17 (Suppl A): A19-20.
29. Siennicki J, Kovacevic-Kuśmierek K, Włodarczyk M et al. Wpływ korekty pochłaniania na skuteczność diagnostyczną scyntygrafii perfuzyjnej mięśnia sercowego. Nucl Med Rev 2014; 17 (Suppl A): A24-25.

30. Filipczak K, Kuśmierek J, Płachcińska A. Porównanie wyników skróconego badania perfuzji mięśnia sercowego opracowanego protokołem „Myovation Evolution" z badaniem pełnym. Nucl Med Rev 2014; 17 (Suppl A): A23.

31. Piszczek S, Osiecki S, Mazurek A, Budzyńska A, Dziuk M. Czy dodatkowe akwizycje w położeniu na brzuchu w ocenie zaburzeń perfuzji ściany dolnej mięśnia sercowego za pomocą skanera CZT zmieniają postępowanie diagnostyczno-terapeutyczne? Nucl Med Rev 2014; 17 (Suppl A): A25.

32. Chrapko B, Pachowicz M, Nocuń A, Głowniak A, Wójcik M. Ocena układu adrenergicznego serca $w$ zaburzeniach rytmu serca oraz $w$ schyłkowej niewydolności nerek. Nucl Med Rev 2014; 17 (Suppl A): A26.

33. Mazurek A, Dziuk E, Stembrowicz-Nowakowska Z, Piszczek S, Giżewska A, Dziuk M. Scyntygrafia płuc skojarzona z tomografią komputerową wykonywana za pomocą hybrydowych gammakamer SPECT/CT w rozpoznawaniu zatorowości płucnej. Nucl Med Rev 2014; 17 (Suppl A): A6-7.

34. Kovačević-Kuśmierek K, Kozak J, Bieńkiewic M, Cichocki P, Kuśmierek J, Plachcińska A. Skuteczność scyntygraficznych metod prognozowania wydolności oddechowej u pacjentów kwalifikowanych do resekcji miąższu płucnego. Nucl Med Rev 2014; 17 (Suppl A): A7.

35. Cichocki P, Surma M, Woźnicki W, Bieńkiewicz M, Plachcińska A, KuśmierekJ. Wyznaczenie wartości normatywnych oraz oznaczenie powtarzalności średnich czasów transportu ${ }^{99 m}$ Tc-etylenodicysteiny (EC) przez całą nerkę (MTT) i miąższ nerki (PTT). Nucl Med Rev 2014; 17 (Suppl A): A8.

36. Nocuń A. Porównanie czterech metod oceny perfuzyjnego badania mózgu wykonanego techniką SPECT. Nucl Med Rev 2014; 17 (Suppl A): A9-10.

37. Maurin M, Pawlak D, Garnuszek $P$ et al. Fizyko-chemiczna oraz radiochemiczna charakterystyka kompleksów analogu DOTA-Gastryny (CP04) z radiometalami. Nucl Med Rev 2014; 17 (Suppl A): A27.

38. Cieszykowska I, Mikołajczak R, Janiak T et al. Alternatywne metody produkcji technetu-99m. Nucl Med Rev 2014; 17 (Suppl A): A28.

39. Tomaszuk M, Sowa-Staszczak A, Lenda-Tracz W, Głowa B, Hubalewska-Dydejczyk A. Optymalizacja protokołu badania PET/CT pod kątem redukcji dawki skutecznej otrzymywanej przez pacjentów w trakcie części CT — badanie fantomowe. Nucl Med Rev 2014; 17 (Suppl A): A17-18.

40. Wyszomirska A, Gramek A, Cichocka S et al. Standardowa wartość wychwytu (SUV) w różnych metodach rekonstrukcji obrazu PET. Nucl Med Rev 2014; 17 (Suppl A): A17.

41. Budzyńska A, Braziewicz J, Dziuk M. Ocena skuteczności zastosowania osłony przed promieniowaniem jonizującym $(0,5 \mathrm{~mm} \mathrm{~Pb})$ w pracy z pacjentami poddawanymi wybranym procedurom z zakresu diagnostyki i terapii izotopowej. Nucl Med Rev 2014; 17 (Suppl A): A18-19.

42. Dziel T, Listkowska A, Tymiński Z. Porównanie pomiarów aktywności ${ }^{89} \mathrm{Sr}$ ¡ ${ }^{90}$ Y w zakładach medycyny nuklearnej w Polsce. Nucl Med Rev 2014; 17 (Suppl A): A47.

43. Trojanowska I, Budka Suflera, Tyle samo prawd ile kłamstw. Iza, 1981. 